\title{
Thoughts on the Role of Cavalry in Medieval Warfare
}

\author{
Jack Gassmann, Artes Certaminis \\ Lackgassmann@gassmannconsulting.com \\ KS Trogen
}

\begin{abstract}
This article explores the role of cavalry in medieval warfare starting with it's origins in the Carolingian age, examining how cavalry was used as a strategic asset within the context of the period on at an operational level, as well as the tactics they were likely to have employed. Due to my interest in both medieval warhorses and mounted combat research into the context and use of medieval cavalry was a natural by-product. Using primary resources such as first-hand accounts and period artwork as well as secondary literature, the article summarizes the findings of my research. Most historians, despite the recognition that field-battles were not the heart and soul of medieval warfare, still judge medieval cavalry by their performance within them. My findings show a much greater concentration on small unit actions, both in armament and organization, with cavalry centred on chevauchées on raiding and subduing castles in swift commando type take and hold missions. The diversity of mounted forces are also examined in the context of the lance and the integration of mounted crossbowmen and bowmen for combined arms tactics.
\end{abstract}

Keywords - cavalry, medieval warfare, strategy, armament, small unit actions

\section{INTRODUCTION}

This paper presents my thoughts and observations on cavalry warfare in the Middle Ages and my views of the dynamics ${ }^{1}$ at play. This is not a comprehensive work on medieval cavalry, merely the presentation of a different perspective on the operational doctrine of medieval cavalry in the European theatre from 800 to 1500, using treatises on riding and combat, pictorial evidence from period illustrations, surviving accounts, and secondary sources.

Until recently, the centrepiece of medieval warfare for most historians was the field battle, usually dramatic, well documented and seemingly decisive. The most alluring part of the scene is the cavalry charge, well ordered knights in their iron cocoons on heavy draft chargers colliding into their counterparts or infantry, sweeping them off the field. Surely it was this glorious heavy cavalry charge that marked the knight as the apex predator of the battlefield and secured his social standing (White, 1964:1-2, 7).

\footnotetext{
1 In this article, when I refer to dynamics I'm referring to the basic nature of a cavalry engagement, the circumstances, manner in which they were fought on a personal and unit level and also the tactics and strategies behind the way in which they were fought which are a direct result of the circumstances and doctrine.
} 
Yet, looking at famous defeats of such charges such as Bannockburn, Crécy, Laupen and the Battle of the Spurs by plucky if inexperienced commoners (another stereotype now under fire, see Chandler (2013)), other social historians including the French historian George Duby saw these examples as proof of the knights being useless charlatans, quite capable of fooling around with each other, but useless in a real fight. The knights' ineffectiveness is usually blamed on their supposedly ridiculously heavy armour.

The first stand-point arises from the Victorian application of military history as a teaching tool to instil military principles into young officers, taking medieval cavalry as paradigm of the role of heavy cavalry (Jones, 2008). The second is a view taken by many social historians, viewing it as evidence of the injustice and incompetence of the feudal system. Many recent historians have addressed the two main listed misconceptions. A picture is emerging where sieges and a strategy of battle avoidance is more prominent than all-or-nothing pitched battles (Smail, 1995:11), and a more nuanced social structure replaces a black and white Marxist struggle.

I have come to see that far from being armoured bulldozers rolled out onto the battlefield in massive formations but otherwise lying dormant, feudal cavalry fulfilled the greater part of their use off of the battlefield and far from the column; closer to strike teams in apache helicopters than battlefield behemoths relying on more agile forces to scout and protect their flanks.

I will examine four aspects in my article.

- The origins of feudal cavalry;

- The tactical issues feudal cavalry were meant to address;

- The methods with which they overcame them; and

- And the dynamics of mounted combat on a variety of different levels.

I shall start with the rebirth of cavalry in the Carolingian dynasty and examine the tactics used by the Norman adventurers. I shall then consider the problems that these tactics being copied all over Europe presented for a commander, and examine the tactics that arose to solve them. We shall also look at how cavalry forces were structured and the advantages and disadvantages thereof.

Finally, we will also look at cavalry respectively in field battles and smaller engagements. The focus here will lie mainly on the advantages and problems for cavalry in such engagements, as well as their dynamics. 


\section{A BRIEF HISTORY OF THE DEVELOPMENT OF FEUDAL CAVALRY}

\subsection{An Answer to a Need: Carolingian Cavalry}

Charlemagne and his father's mounted nobles are usually regarded as the beginning of feudal cavalry (Stephenson, 1956:08): noblemen obligated to fulfil military service mounted on horse, comprising the cavalry wing in a fully mobilised field force (Bachrach, 2001:121).

Before the Carolingians, the Franks seem to have preferred to fight on foot, much like their Norse and Saxon brothers ${ }^{2}$. During the Carolingian dynasty, they however seem to have built a potent cavalry force. They did this through a highly sophisticated system of levies, obliging households to provide men based on their incomes; the more prominent land owners were obliged to provide horsemen (Bachrach, 2001:55).

This newly formed cavalry force was effective and aggressive, often riding far ahead of the infantry forces. They were often called up for smaller campaigns and then operated with minimal infantry support in order to spare the infantry from a sustained absence from their farms. They trained extensively, including mounting and dismounting in full kit and mock charges in which one side wheeled away at full gallop to become the pursued, only to become the pursuers once again as they wheeled back on their opponents (Bachrach, 2001:55) - a highly impressive feat of horsemanship which most modern equestrians only dream of. Carolingian cavalry was obliged to carry bows besides body armour, helmets, swords, lances and shields (Delbrück, 2000:29).

Charlemagne's reign saw a massive growth in the cavalry wing. The mustering was even moved to the spring in order to give better fodder for the horses. It also saw the fortification of settlements and manors, as well as the creation of the Scara. The Scara, from which the modern German word Schar (band, crowd) derives, were bands of young noblemen, almost certainly mounted, assigned to a nobleman's court or border outpost, who were on constant war footing and served as a quick response force against any threats in the area. They could also serve as garrisons on frontier forts, and the larger ones could orchestrate small military expeditions independently (Bachrach, 2001:80).

Both fortifications and the Scara were responses to the dangers posed by raiders and bandits on the frontiers (Bachrach, 2001:81). The birth of Frankish cavalry followed a need for a highly mobile force that could be called upon at any time to raid as well as protect against raiders, find and pursue the enemy, serve on protracted campaigns, and field experienced soldiers that could serve as the core of an army - besides keeping the peace and serving as a standing force to ensure the peace of the land, so making trade possible. It was a successful concept: eventually, Frankish cavalry was to sweep across Europe, then first contain and finally defeat the Magyars (Reuter, 1999:17).

\footnotetext{
2 See on the matter the emperor Maurice's Strategikon, book XI, ch. 3 (ed. Dennis 1984)
} 


\subsection{The Birth of a New Age: Norman Tactics}

Fast forward two hundred years to the poster boys of the couched lance charge, the Normans - sweeping Italy and England with their couched lances, smashing their opponents to bits (Gillingham, 1999:65).

But when historians questioned this, the realities proved to be somewhat different. At Hastings, the Norman cavalry suffered heavy losses, and it was only a feigned rout that facilitated a victory. The Bayeux Tapestry is oddly silent on the couched lance aspect; the vast majority of lances are carried over-hand or under-hand - high, ready to throw, or low, ready to stab ${ }^{3}$. At the battle of Civitate in 1053, the presumed herald of a new era of shock cavalry, 700 Swabian infantrymen kept thousands of Norman horsemen at bay after all other forces fled.

The strategy employed by the Normans in Sicily, far from one of riding down their enemies in showy engagements, was one of a small force seizing a stronghold in a lightning assault, using short but furious raids to subdue the surrounding country-side, and then exploiting the gains to draw in further reinforcements. Trading the longboats of their forefathers for horses proved to be highly effective.

The Normans, wherever they went, combined ambition, quick decisive action, a willingness to gain victory through underhanded means, and a long-term policy of building defensive strongholds to hold and solidify their positions - a potent mix that allowed them to keep a toe-hold in the Holy Land for almost two hundred years, with their supply base over 2000 miles away, something modern powers would later struggle to maintain (Gillingham, 1999:65).

\subsection{Conclusion}

The Carolingians took as original base the Germanic tribal warrior hierarchy and adapted it into a cavalry force to fit their needs. The growing Carolingian empire faced a three pronged problem: first to create a solid, well-rounded force that could be used in multiple theatres of war against varied enemies without resorting to comprehensive levies that would leave the threat of a coup looming in the distance; second to do this without destroying their economic base by dragging vast amounts of the population on protracted campaign; and third to defend, control and reign a growing empire.

They chose to do this by instituting policies that promoted the creation of a mounted elite tied to the nobility, flexible enough to rapidly redeploy and serve in a multitude of roles. It was a small elite that created the backbone of any expeditionary force or could act independently, calling on further support when needed. Since the core had no actual ties to a specific region's levy, the auxiliaries for recurring campaigns could be rotated in order to spare the region.

The Normans developed the capabilities of the cavalry elite. They fully exploited the offensive capabilities of the force's mobility and expertise, adapting their potential to

3 Bayeux Tapestry (<1066). Bayeux, Musée de la Tapisserie de Bayeux. 
siege warfare. They also put the independence of the construct to the test during the Italian campaigns, working on a purely freelance expeditionary basis with little to no formal support, relying on the expedition's own success and a refined feudal system to provide both supplies and reinforcements.

These tactics, however, relied on the mobility and flexibility of a small force, an approach which has more in common with modern special forces than Marshal Ney's massed sabre charges.

\section{PROBLEMS FACED BY A MEDIEVAL COMMANDER - THE LANDSCAPE AND ITS CHALLENGES}

As a result of the rapid adoption of Norman tactics, the landscape was soon dotted with small stone keeps, each one a fortress in its own right. Each one was defended by a nobleman whose personal identity was based on martial skill, raised from birth hearing the exploits of his forbears and taught from a young age to ride, fight and command (Verbruggen 1997).

Let us examine the problems that such a landscape presents to the medieval commander from an offensive viewpoint. For one, we must remember that especially in the High Middle Ages, logistics were far from simple; it was not always easy to find large stores of provisions, nor the cash to purchase them. Columns accompanied by supply trains move at a pace of 1.5-2 miles per hour and 15-20 miles per day, a limitation that did not change from Alexander to Napoleon (Keegan 1978:304).

Should a medieval commander proceed with a substantial column, by necessity he must proceed along established roads or waterways. In doing so, he will inevitably hit a castle or fortification. The castle, due to the slow advance, naturally has had time to prepare. The commander is faced with three choices: 1 ) besiege the castle with his entire force; 2) ignore it and march past; or 3) leave a detachment to besiege the castle.

- Option 1 - a siege - bogs down his advance; a siege could take weeks, therefore prove a substantial financial burden and pose the danger of a relieving force taking his encampment in the rear. A frontal assault could easily prove disastrously costly, as the combination of defensive architecture, bodyarmour and trained and determined personnel was and still is a force multiplier that is not to be underestimated. A simple doorway or staircase could turn into a kill-zone.

- Option 2 - marching past - leaves the garrison (usually a nobleman of some kind and his retinue) to raid his supply line and harry his retreat should he be defeated.

- Option 3 - split the force - means that, should the attacker pursue the tactic at subsequent obstacles, the column would be left drastically weakened. Each force tasked with containing the defenders is dangerously vulnerable to even a small relieving force or constant sallies by the defenders. 
None of the three options is particularly attractive, and examples of commanders choosing between them and the results thereof can easily be found.

\section{OPERATIONAL DOCTRINE}

\subsection{The Knight as a Military Asset}

Although "knight" can be an exact feudal rank, it can just easily refer generically to a member of the second estate. It is a simple case of "all kings are knights, but not all knights are kings". The simple feudal contract was land for services, an estate in return for personal military service. Although the reality became much more complex towards the end of the period, it was this that remained the basis. It was this military obligation that defined the identity of the $2^{\text {nd }}$ of the three estates, "those who fight" (Stephenson 1958:58).

The funding provided through the knight's fief meant that he could, and was obliged to, equip himself with armour, providing a level of protection against contemporary weapons that modern militaries struggle to match (Verbruggen, 1997:61). So strong was the rooting of the second estate in the craft of war that, should he no longer be able to afford his equipment, he was demoted to the third estate (Tuchman, 1987:18). The $2^{\text {nd }}$ estate spent their days hunting dangerous game such as stag, boar and bull off horseback with sword and spear (Dom Duarte, ed. Preto \& Preto 2006:100-115) and engaging in tournaments, when not taking part in actual warfare.

Hunting has in my view is much underestimated in its importance in the training of medieval cavalry. The very act of organizing a hunting party has military application; organising and provisioning a hunting party is an exercise in military logistics (Norridge, 2005:163-4). Machiavelli emphasises the importance of hunting for reconnaissance (Marriott \& Baker-Smith, 1992:51). The pursuit of the quarry has elements of riding and force coordination. Once found, the quarry had to be killed, not always a simple task, even with dogs keeping the quarry at bay. Duarte devotes much time on how to accomplish this task without endangering horse or rider, a test of riding skills similar to modern bullfighting. It tested the cutting power of warriors' strikes, and also accustomed a fighter to seeing the effect of his strikes on living flesh (Dom Duarte, ed. Preto \& Preto 2006:115). The social aspects of hunting would have promoted command skills, unit cohesion and esprit de corps within the household.

Surviving fencing manuals of the $14^{\text {th }}$ and $15^{\text {th }}$ century, written by masters attached to noblemen's households, testify to the martial perfection granted by a lifetime of practice and generations of experience. They show highly sophisticated martial arts systems for dagger, for poleaxe, for long-sword and a long list of other weapons, each covered in detail, both armoured and unarmoured, foot and mounted. The mounted techniques show a level of horsemanship gained only through a youth spent on horseback. Though it is hard to prove to what extent knights practiced and were skilled in these martial arts, Fiore lists among his students Piero Paolo del Verde, Niccolo Unricilino, Galeazzo 
Cattaneo dei Grumelli, and Lancillotto Beccaria di Pavia 4 Roger of Hoveden wrote, referring to the sons of Henry II of England:

They strove to outdo the others in handling weapons. They realised that without practice the art of war did not come naturally when it was needed. No athlete can fight tenaciously who has never recieved any blows: he must see his blood flow and hear his teeth crack under the fist of his adversary, and when he is thrown to the ground he must fight on with all his might and not lose courage. The oftener he falls, the more determinedly be must spring to his feet again. Anyone who can do that can engage in battle confidently. Strength gained by practice is invaluable: a soul subject to terror has fleeting glory. He who is too weak to bear this burden, through no fault of his own, will be overcome by its weight no matter how eagerly he may rush to the task. The price of sweat is well paid where the Temples of Victory stand (quoted from Verbruggen 1998:28)

It is safe to say that it is hard to conceive of an entire subculture more centred around the practice and glorification of war. The literature that a growing boy from a noble house would come to into contact with had one message confirmed by social expectation, that personal worth was bound to fighting ability (Bumke, 1999:439).

Motivation to warfare was not only social; warfare could provide a valuable means of supplementing income. If lucky, ransoms could be made or loot taken, equally new lands could be gained (Verbruggen, 1997:49-50) For younger sons who did not choose to become clergy, military adventuring was practically the only career option available.

Since knights were provided with extensive preparation for warfare and were not limited by the training and resource constraints of later cavalry, which forced roles to be separated, it is almost unthinkable that they would have been limited to the role of "heavy cavalry" normally ascribed to them in literature.

In his article "Re-thinking the origins of the 'Irish' hobelar" (Jones 2008), Robert Jones shows that hobelars were more valuable for their expendability and raw numbers than for performing a task that knights were unable to do. He cites examples of knights and even monarchs performing reconnaissance and small action engagements. As we shall see, knights also performed further tactical niche roles that would today be deemed light cavalry assignments. They were equally capable of fighting dismounted in sieges and field engagements, such as the French and English at Agincourt and Poitiers and the Habsburg forces at Sempach.

The mounts that knights preferred seem to be, contrary to the modern stereotype of the medieval warhorse, small by modern standards: 14 to 15 hands and of relatively light build $^{1}$ (Clark, 2011:170) The best warhorses came from Spain and Italy; Spanish horses have always been known for their manoeuvrability (Davis, 1989:49, see also Bumke, 2008:239).

4 Fior di Battaglia, ca. 1400. New York, Morgan Library, MS M.383, ff 1rCity:- 
The feudal cavalry detachments could be capable of extremely rapid movement. In 1173 Henry, while fighting against rebellious Breton barons, made a lightning ride of $240 \mathrm{~km}$ from Rouen to Dol in little more than a day (Hyland, 1996:104). A cold blooded draft would not have been able to keep such a pace.

Quality horseflesh seems to have been of such vital import for the Teutonic Order in its Razzia (raids equivalent to French or English chevauchées) that they were considered a strategic asset, since their Lithuanian enemies only had access to apparently inferior native ponies. The warhorses of the Order (invariably stallions) were sterilised using a method of strangulation of the spermatic cords; the result was a warhorse which retained the needed testosterone to promote the desired muscle growth and the aggressiveness for the close combat preferred by European cavalry, but was, if captured, useless for breeding (Akdahl 1998).

\subsection{Unit Composition}

What did the basic unit composition look like? In this case, we are somewhat plagued by terminology: In the High Middle Ages, there was no firm name for a cavalry force, nor any firm norm of how it was to be composed, nor are there many detailed descriptions of the exact actual composition of such forces.

So let us look at the term that replaces it: Lance, glaive or helm, terms that arose in the mid $14^{\text {th }}$ century, were terms for a knight and his retinue. Going back to the $13^{\text {th }}$ century, the basic "lance", though not yet bearing the name, seems to have been a knight, his squire and a servant of some kind (Delbrück, 2000:361) The main job of the squire was to lead the warhorse at the ready, while the knight rode his spare mount in order to keep the warhorse fresh for combat, or in the case of battle, to switch out mounts and defend the baggage. This aspect seems to stretch back to the Celtic cavalry practice of the Trimarkesia:

The army that gathered was 152,000 infantrymen and 20,400 horsemen: that was the number of the cavaly always in action, but the real number was 61,200, as there were two grooms to each horseman, all mounted and good riders. When the Gaulish cavalry were in battle, the grooms would stay behind the ranks and make themselves useful with new mounts when a horse or rider fell, but when a man was killed, the slave would mount the horse in place of his master. If man and horse both died, he was ready mounted. When they were wounded, one of the slaves took away the wounded man to camp, while another stepped into the line in his place. [...] In their own language they called this division trimarkisia; you should realise marka is the Celtic word for 'borse'. This was the armament and this was the resolution with which Brennus marched on Greece 5

5 Pausaniae Veteris Graeciae descriptio, 10.19.4-23.9 (Levi 1984) 
This coincides with Templar statutes:

The Confanonier was to arrange the squires also into squadrons, when the Marshal led the brother knights in the charge, the squires who rode the spare destriers were to charge after them. This animal provided a remount if their master's charger was wounded or blown. Meanwhile, those with the palfreys or mules which the knights rode to battle, were to follow the Confanonier's banner, well-ordered and at the amble (Bennet 1989)

The squires are not usually spoken of as having a direct combat role; however, it is rather backwards to say that they had no combat role. Should an enemy break through or attempt to encircle, they doubtless would have been immediately involved in combat; they also most likely played a much larger part in foraging, skirmishing and pillaging (Delbrück, 2006:315). It makes sound military sense to expose the upcoming personnel to combat and involve them in the fight, while sparing them the greatest danger. Current knights can be replaced by their squires; mature older knights can not be made younger.

In Chaucer's Canterbury Tales, the group is accompanied by a knight, his squire and an archer in the service of the knight, also well mounted (Coghill, 1994:18). In the Manesse Codex, there are two pictures of riders armed with crossbows alongside lancers; one is the picture on the right (Ill. 1)

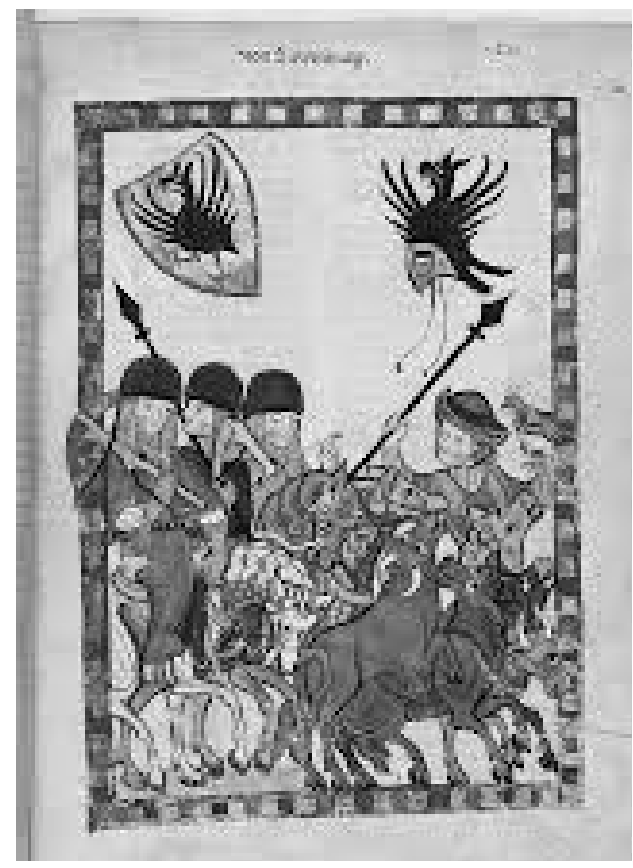

Ill. 1: A late 13th century depicting mounted crossbowmen.

Anonymous, Manesse Codex, 1310-1340. Heidelberg, Universitätsbibliothek, Cod. Pal. germ. $848, f^{\circ} 359 r$ 
Riders with bows can also be seen in the Morgan Bible. The same can also be found in the St. Gallen Golden Psalter, which dates to the late $9^{\text {th }}$ century AD. A mounted archer is also included in the Bayeux Tapestry 6 .

Crusading knights were obliged to provide crossbowmen or archers as support. It seems however that in general, they were not mounted, unsurprising given the scarcity of mounts in the Holy Land (Delbrück 2006:361). The Teutonic Order made great use of the crossbow and was famous for exporting mounted crossbowmen (Akdahl 1998).

Specifically mounted crossbowmen seem to start to appear in the $13^{\text {th }}$ century. In 1239 , Raimond VII of Provence promised to send the pope 40 knights and 10 mounted crossbowmen (Contamine, 1986:67). This can either be interpreted as separate divisions of mounted crossbowmen added on to the main force, or as auxiliaries already attached to the household of the commander or the knights themselves. The second seems to me much more plausible. Keep in mind that a force of forty knights must be multiplied at least times three to accommodate squires and sundry personnel anyway. Probably, the number of crossbows is listed in much the same way the exact number of special weapons would be listed in a modern force.

Bow or crossbow elements were essential to medieval forces. Mounted longbowmen constituted a large number of the English expeditionary corps. The German "gleves" of the $15^{\text {th }}$ century usually consisted of 3-4 men, one of these armed with a crossbow (Beck 1911:133). The Burgundian "lance fournie" was defined as "at least six men and six horses a man-at-arms and his two assistants, plus two mounted archers, having at their common disposition a valet or mounted servant" (Contamine, 1986:129). The entire group was well mounted, usually also with spare mounts (Contamine, 1986:68-71).

The integration of ranged components therefore evidently was a longstanding and widespread one.

It is however worth emphasising again the random nature of lances in muster rolls. Sometimes, a lance could even mean just a single man-at-arms without support. The size of lances could vary greatly, anywhere from 1 to 20 men, depending on time, location and the importance and nature of the nobleman it was centred around (Delbrück, 2006:315) It is not unreasonable to assume that early groups followed the basic structure of men-at-arms supported by ranged auxiliaries.

Upon examination, a lance is a self-contained unit of specialists ideally suited to operating independently behind enemy lines. Once again, not unlike modern special forces, and as we have seen, their preferred duties and level of training were not that unlike those of their modern counterparts. The fact that all elements were well mounted and could move with speed, especially when operating within range of a supply base, meant they were ideally suited to everything from harrying an enemy column to skirmishing and take-and-hold missions.

6 Bayeux Tapestry, the mounted archer ist to be found directly after the death of Harold, pursuing fleeing Saxons 
Many believe that the archers and crossbowmen, although mounted, most likely dismounted at the first sign of the enemy. However, $15^{\text {th }}$ century "fight-books" give explicit instructions on how to use crossbows to their fullest on horseback, and even how to fight mounted men-at-arms with them ${ }^{7}$. The King's Mirror lists them among the weapons a horseman should be able to employ while mounted (Larson, 1848:220). As I have mentioned above, it is common to find a few mounted archers or crossbowmen mixed into a mass of charging cavalry in artwork from 800-1500; this is especially true if it is depicting a cavalry force trying to take a fortified position, weapons aimed high in order to give covering fire to comrades.

The conclusion on unit composition is that the typical medieval force was a mobile operational unit that can be amalgamated into small to mid-size groups, depending on task, flexible enough to take on a variety of assignments. The above picture from the Wolfegg manuscript (ill. 2) shows a column on the march; on the left and right are the cavalry forces. Note the typical unit structure of the lance; mounted crossbowmen are combined with close combat personnel.

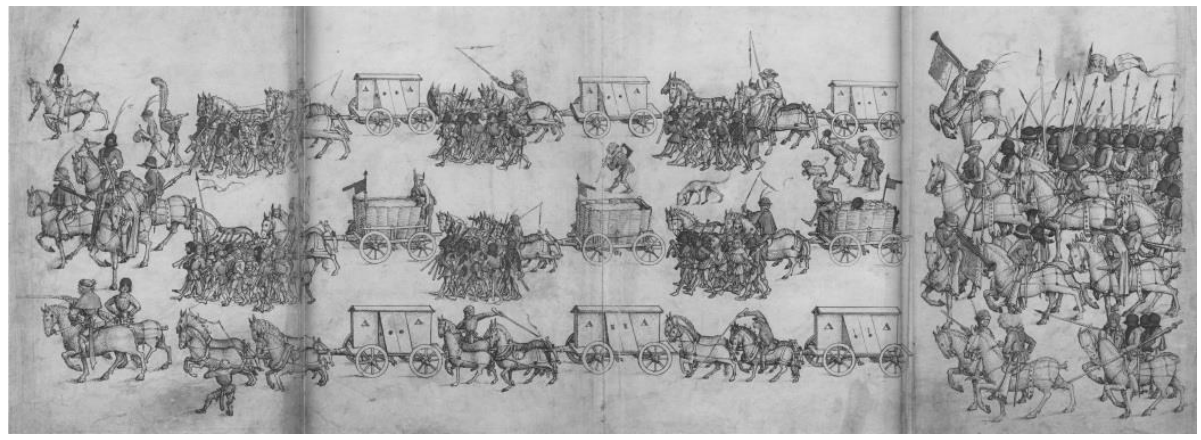

Ill. 2: An army on the march from the Wolfegg manuscript, note the mounted crossbowmen at the head and rear of the column.

Anonymous, Venus und Mars. Das mittelalterliche Hausbuch aus der Sammlung der Fürsten von Waldburg Wolfegg, 1480. Ed. [facsimile] Waldburg Wolfegg, Christoph (1997). New York: Prestel, fo $51 \mathrm{v}-52 \mathrm{r}$.

\subsection{Warfare and Operational Doctrine}

The medieval commander had to contend with a landscape and economic situation that made mass movement of forces extremely hard and militarily inefficient.

Economic power lay in the land and its productive capabilities. No land could be permanently held without the destruction or capture of its defensive installations or the treachery or destruction of its defenders. He who controlled the castle controlled the land. Any concerted mass attack into the enemy's heartland which ignored these realities

${ }^{7}$ See Talhoffer Fechtbuch (MS Thott.290.2º, Talhoffer Fechtbuch (Cod.icon. 394a) 
could easily be blunted or picked apart with little danger to the defender. Attempts at a slow siege-by-siege approach were likely to end in either economic or military ruin for the attacker.

The task of tackling this problem was left to feudal cavalry. In a time before reliable explosives, the option of destruction was a moot one, as one would have to be in total control of the installation to destroy it, and if one wished to hold the land, a new one would have to be built. The mobility and flexibility of feudal cavalry offered a solution.

A small elite force is exceedingly well suited for lightning operations; whereas a column could not take a castle by surprise, feudal cavalry could. If a castle could be reached before the gates were closed, or an escalade could be made by night, the attackers could take it with minimum loss. This is a frequent theme of both historical record and period romances (Harari, 2009:10-21)

The mobility of feudal cavalry was also well suited to the alternative: burning and plundering enemy holdings and assets served the triple purpose of leaching the enemies supply to strengthen your own, weakening their morale and goad them to a fight on equal grounds (Verbruggen, 1997:281).

These objectives were achieved in small-scale raids called Reyse, chevauchée, cavalcado or by various other names, most of which seem to have their root in "caballus", horse. They comprised operations often behind enemy lines by small groups, usually of cavalry.

The goal was to move with Caesar speed to destroy local infrastructure or take defensive installations before a proper defence could be mounted. The destruction of infrastructure was often spiced with a copious terror tactics, directed against the local population (McGlynn, 2008:chap.5), with the goal of luring the defending forces out of their fortress into the open.

The second great tool for the medieval commander was of course treachery and intrigue. Medieval accounts abound with accusations of treachery, and it is a constant companion in medieval literature (Harari 2007). However, these treacheries often depended on the effectiveness and speed of the small group that could be convinced of, or trusted with, the intrigue.

The small private wars fought all over Europe from the early to late middle ages followed this pattern of brutal expeditions and underhanded means (Verbruggen, 1997:29).

Probably the best and most pertinent example for a practitioner of the private war in the Lichtenauer and other early German traditions is the "Fehdebrief". It translates literally as "feud letter". It was delivered to the rival nobleman and handed over by the means of a cleft stick to keep the messenger out of arms reach. The contents usually gave a date at which hostilities were to begin and the grounds for the declaration of war.

The private war that ensued usually only concerned the noble houses of the offender and the accuser thus at most a few dozen combatants unless the two houses were major 
players who could call in the backing of other houses, each would try and destroy the production base of the other, neither particularly keen on facing the enemy head on, as losses in men and horses could be devastating in the long term, both politically and financially. It is worth noting here that excepting, the princes and cities, most noblemen only supplied a handful of gleves (Zeumer, 1913:232) (the German version of lance fournie, usually consisting of four men).

The terror tactics had a further, deeper meaning: The position of the $2^{\text {nd }}$ estate was based on its ability to protect its vassals; therefore, attacks on the peasantry not only undermined the supply base, but the very justification for the enemy's existence.

These tactics are often criticised for being hypocritical, going against the dictum to protect the third estate, but to do so is to misunderstand the nature of feudal obligations. The contract between third and second estates was on a private basis; the obligation was to the liege lord's own vassals, not his enemies'. In these feudal contracts, if one of the entities failed to deliver on their part of the deal (as in any contract before or since), the other part was not bound, either. This undermining of local authority sometimes took the form of peasant revolts, the most famous of these being the Jacquerie in France (Barbara Tuchman, 1978:176)

Chevauchées could also be used to cover the movements of troop columns as the Black Prince did in his Grande Chevauchée (Burne, 2002:250-259 and McGlynn, 2008:233238). This third aspect brings with it an interesting insight into the savagery behind the movements of medieval armies. Besides the need to supplement supply from the land and supplement troop pay, it was of absolute military necessity that the surrounding country be subdued beyond the point of resistance both on a tactical and psychological level. A failure to do so would expose the column to attack.

If a substantial force was gathered, battle was denied until a suitable opportunity to strike was found. This often came in the form of a siege or otherwise vulnerable position. Once the enemy was discovered in such a situation, it was paramount that one could confront the opponent before the opportunity was lost ${ }^{8}$.

From this we can conclude that the standard operational doctrine of feudal cavalry was, on the offensive, to act in small independent units in order to, if possible, take the enemy by surprise, either through speed or treachery, and gain entrance into the fortification. Should this fail, the next step was to plunder the enemy infrastructure until they responded, in order to draw them out for an ambush. Should the defender decide not to confront the raiding force, the raiding continued until the defenders either capitulated to the attackers demand, their own vassals rebelled or the raiding no longer produced enough yield for the attacker to finance the action. The dangers of moving in

8 For a masterful application of this strategy, see Edward I's campaign against Simon de Montfort (Morris 2008:67-68) 
column could be avoided if the defending garrisons could be effectively suppressed by the column's cavalry detachment, forcing the defenders into their strongholds.

Defensive doctrine consisted of either raiding attacking forces from a position of strength or retreating to a position of strength and waiting for the attack to pass. Alternatively, both sides could raid each other in an attempt to force the other to concede first. If besieged, the force could retreat and wait for either a relieving force to come to their aid or the attacker to be forced to retreat by finances or a threat to his own lands.

\subsection{Conclusion}

The operational doctrine of medieval cavalry consisted of mass raiding on personal initiative, often operating behind enemy lines. The goal of the raids was to take strongholds or force their defenders out to fight.

Defensively, the tactic was similar: to raid exposed targets and retreat to safety when threatened.

Due to mobility, unit size and elite nature, feudal cavalry could also be used to exploit treachery or carry out clandestine missions (Harari 2007).

The general operational doctrine seems to be one that could be described as direct action special warfare.

Moreover, the methods employed suit neither heavy nor light cavalry, much more a mix of the above; the problem is further compounded by the fact that the unit composition meant that specialists were grouped together, instead of being separated into divisions.

If a larger raid needed to be performed or a position held, several lances could easily be grouped together. This seems to me a much more elegant system, considering the nature of medieval warfare, than separate divisions of cavalry given different tasks, as was to arise in the $17^{\text {th }}$ century.

This operational doctrine led to an odd paradox: although defensive capabilities far outweighed offensive siege techniques, forces needed to stay highly aggressive in order to take the fight to the enemy and avoid having to fight a defensive war. This dynamic warfare, which put more emphasis on mobility and the element of surprise than brute force, was the natural habitat of the knight, and thus most likely defined his martial upbringing and tactics - not the battlefield. It is interesting to contemplate that the ideal of Arthurian romances, a knight wandering, seeking wild adventure and the terrible monsters that prey upon his realm, is perhaps closer to the reality than one may at first think.

\section{REALITY AND DYNAMICS OF ENGAGEMENTS}

\subsection{Field Battles and the Dynamics at Play}

Even if the battlefield was not the day-to-day reality, then was it an ideal? The ultimate application of the skills learned in a lifetime of guerrilla warfare? It seems not even that. 
The most prestigious engagement of the $14^{\text {th }}$ century was "The Combat of the Thirty", an insignificant skirmish by $19^{\text {th }}$ century standards, which set two groups of thirty knights against each other in a formally arranged combat and which awarded its participants the celebrity status of war heroes:

More than twenty years later, Froissart noticed a scarred survivor at the table of Charles the $V$, where he was honoured above all others. He told the ever-inquiring chronicler that he owed his great favour with the king to his having been one of the thirty (quoted from Barbara Tuchman 1978:131).

The parties were honoured far beyond any of the participants (with the possible exception of the commanders) of the large field battles of the Hundred-Years'-War. Medieval romances prefer to dwell on personal duels and heroic deeds than tactical genius on the battlefield, or even the battlefield itself. The habit of duels before a battle was common (Dlugosz, ed. Maurice, 1997:518), a tradition that survived in cavalry regiments up into $1^{\text {th }}$ century English dealings in India (Kinsley, 2012:98). In personal memoirs, minor engagements (to the fury of some researchers) are sometimes described in much greater detail than more significant field engagements (Harari, 2004:3).

Simon de Montfort fought in his lifetime a total of two battles and was considered a great commander before the battle of Lews. Richard the Lionheart in his years of active warfare fought one known field engagement, Arsuf, which was more a large-scale harassment of his column than a conventional battle.

Modern researchers have come to see a pattern of denying battles, which figures more highly than an active policy of seeking them (Nicholson, 2004:113). So it seems for medieval cavalry, a policy of large scale skirmishing was preferred over one large, all-ornothing engagement - but why was this?

First, battle was a terrific gamble; field battles were often bloody and not always decisive for one side or the other. Losses suffered by feudal cavalry were especially hard felt, considering that it was not only a loss of personnel, which required years of training from a limited recruiting base, but also a political loss, as the lost knights also served a ministerial function. The ensuing loss of expensive equipment, including horses, which required extensive training, is not to be underestimated.

When a cavalry force chose to give battle, it was often disastrous, should they face wellorganised infantry (Verbruggen 1998:47). This should not be surprising if one examines the dynamics of mounted combat.

A fighter put on a horse is faced with the problem of the surface he must defend more than doubling, without a coinciding increase in the capability to defend it. An armoured horse that actively attacks and avoids attacks mitigates the issue somewhat, but comprehensive horse armour does not become common in art until the beginning of the $16^{\text {th }}$ century, and any attack the horse makes exposes it to a counter attack.

In a frontal assault, the horseman is obliged to expose the horse's neck and head to enemy attack, without the corresponding reach to defend them. This is usually equalised 
by giving the horseman a lance, which extends his reach, and forces his opponent to address the threat before he is capable of attacking the horse. Lances however often broke in combat or could be discarded in order to fight at closer quarters, leaving them unavailable for the next action. Infantry could also be armed with spears or lances, bringing both parties to parity.

The initial delivery of the charge can be enough to destroy the first lines of an enemy formation, demoralising and disorientating them, provoking a rout; should this happen, a horseman is ideally placed to hack down his fleeing foes. Should the infantry hold, a horseman is very badly placed indeed, jabbing with his lance down at an enemy's well protected left side while his horse's most vulnerable area, the often unarmoured neck or bare legs, lies at the infantrymen's mercy. Should his lance have broken at the charge, he must draw his sword, which - even if of the longer variety - is not going to reach much past his horse's head.

Having been in this situation with my horse even in the in the context of friendly reenactment, it is not a prospect I relish to any degree. A strikingly similar assessment of the situation can be found in a Breton chronicle referring to the battle of Bouvines:

Our knights were much afraid of these foot-soldiers armed with lances, whom they had to fight with their swords and short weapons. The lances were longer than swords and daggers and their impenetrable ranks in the form of a crown were as a wall (quoted from Verbruggen, 1997:47).

One must also take into consideration that the larger the cavalry force, the harder it is to manoeuvre; an infantry force is actually much more manoeuvrable in formation than a cavalry force. Due to the oblong nature of horses, sharp turns are harder to coordinate. A large attack must be coordinated so that the line hits as one (Bennet, 1989:4); this means that the entire line is more or less limited by the slowest horse, sacrificing speed and therefore force.

If this sounds like a recipe for disaster, that is because it is. This is born out by an action report told by Usamah ibn Munquidh, an Arab chronicler who leaves us his memoirs: A force of Arab infantrymen, having taken a hill, prepares to defend the position. The Frankish commander orders his knights to take the position. After a series of unsuccessful charges, the commander grows impatient - he admonishes them and asks why it has not yet been done.

The knights answer that for fear of their horses, they dare not drive the charge home and use their lances fully. Upon which the commander replies that since the horses are his property and his concern, they are to drive the charge home with no regard to losses. The knights charge and charge repeatedly, but are unable to drive off the Saracen defenders. According to Usumah ibn Munquidh (ed. Hitti, 2000:96), the Franks lost in that single engagement more than seventy horses, a number which if not inflated would have been a serious blow to the Frankish commander's war effort.. 
Cavalry against cavalry tended to fare better, as the problems of defensibility and manoeuvrability were common to both. The early medieval period saw several comparatively large if rare cavalry engagements. Accounts show that in symmetrical cavalry engagements, a solid formation was crucial in order to make a difference (Verbruggen 1997:97-102). It is hard to be sure of what happened after the initial impact of the two groups. Still, there are hints that one may glean from the sources. Usamah ibn Munqidh's accounts give some of the most explicit insights. He gives no exact description of cavalry combat, but the descriptions he gives of chasing down, intercepting, and escaping opponents that build the meat of his accounts, rule out the possibility of a static scrum.

This is not to say that cavalry engagements could not degenerate into static brawls there are times when a certain character in one of Usamah's anecdotes becomes trapped by the opposing forces. But overall it seems the nature of cavalry engagements tended towards an initial clash that set the tone of the engagement, one line breaking through in parts and a second phase of dynamic manoeuvring. (Hitti 2000:97) Louis Edward Nolan in his treatise implies similar dynamics:

If you bave succeeded in overtbrowing the enemy's line, your own will be in disorder. The melee which ensues, soon, however turns into a pursuit and (Ill. 3) this affords the opportunity of destroying those who bave turned (quoted from Bennet 1989:3).

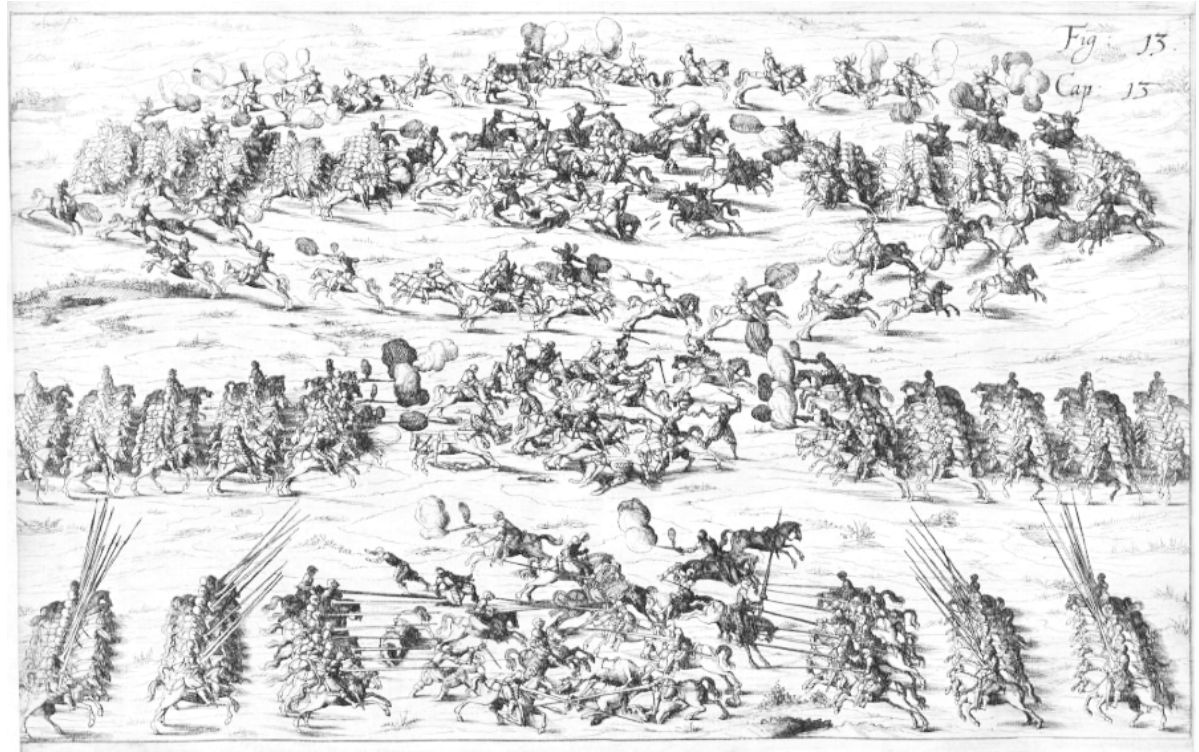

Ill. 3: A depiction by Johan Jacobi von Wallhausen showing how a cavalry starts to break on contact

Johan Jacobi von Wallhausen, Ritterkunst, Frankfurt am Mayn bei Iennis, 1614, p. 113. 
Most medieval portrayals of cavalry charges depict the lines being broken through or the moments before the clash. Often, the lines of the charge are head to croup9. This however stands in stark contrast to later cavalry manuals and practices, which by necessity leave a substantial gap between lines. Johann Jacobi van Wallhausen shows cavalry manoeuvres in his manual on cavalry combat. There are several different styles of deployment, but they all show cavalry ranks with a gap between each other, colliding and mixing. I find this to be well demonstrated in the above picture, taken from his letter to William of Orange written in the form of a military treatise (Wallhausen, 1614:112) Though lacking the plethora of manoeuvres depicted in his work on cavalry drill, it demonstrates the concept admirably.

The natural disadvantage of such an open engagement is of course its vulnerability to a second wave of formed cavalry. This was a tactic that was not unknown to medieval commanders, and reserves were kept for such a purpose (Verbruggen 1997:105-6.). It was exactly this tactic of waiting until the battle lines had loosened, then making a decisive attack, that the Duke of Flanders in William Marshal's time was famous for, and William Marshall himself used in mass tournaments. In this context, the high importance put on the banner carrier in Templar regulations is put in perspective, as a quick collection around the banner in order to counter-charge or execute an ordered retreat is crucial (Verbruggen, 1997:91-7).

\subsection{Small Unit Action and the Dynamics at Play}

Engagements between small cavalry (10-30) forces against groups of infantry of 40-80 actually suited medieval cavalry better than large field engagements. In small engagements, a cavalry force, because of its greater mobility, would have been able to pick the location and therefore use cover to make the range of the charge as small as possible. This minimised exposure to enemy fire and maximised the element of surprise, hopefully catching the infantry before they could properly deploy.

A small cavalry force is much more manoeuvrable than a large one, making it possible for a small cavalry force to circle around to the flanks of a small infantry force at the last second. It is less limited in the speed of its charge as the line is easier to hold steady during the charge. Smaller forces also minimise the political strains between commanders always present at the larger battles. The above illustration from Diebold Schilling (Ill. 4) gives a good idea of what such an attack may have looked like.

\footnotetext{
9 The Illustrations in Sébastien Mamerot, Les Passages d'Outremer, 1472-1475, f 33 r being a good example
} 


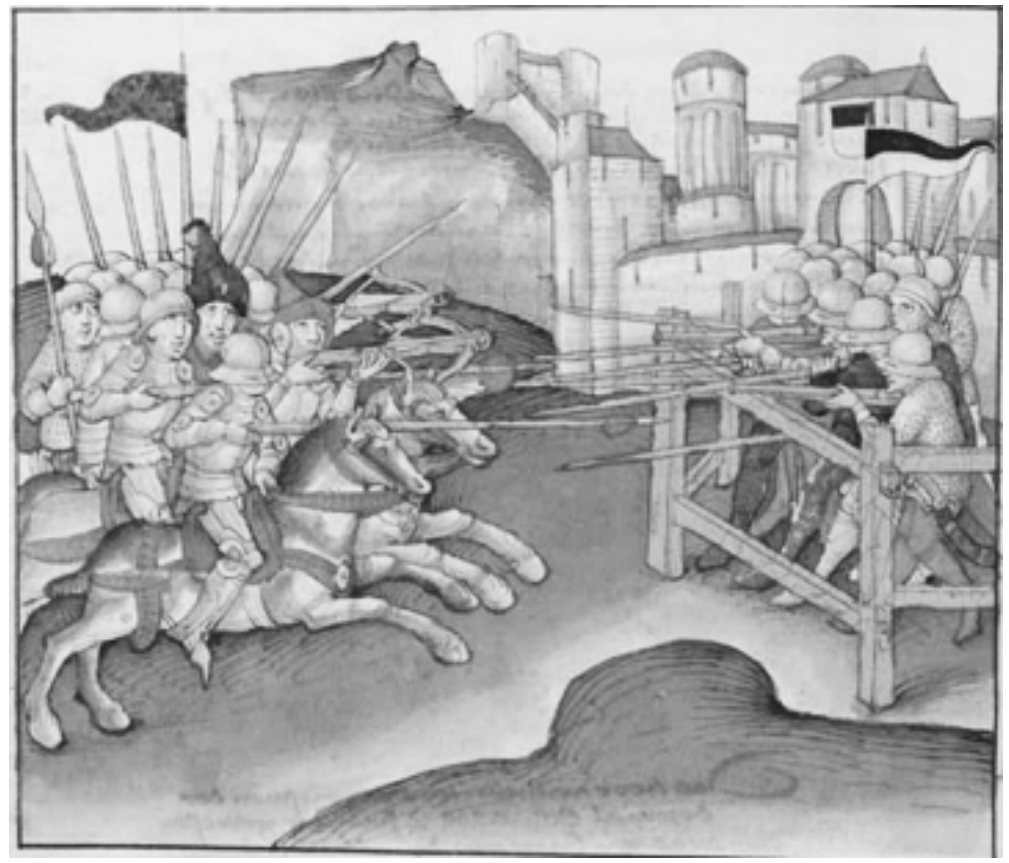

Ill. 4: A group of cavalry attacking a barricade using fire from crossbows to cover their advance.

Diebold Schilling, Spiezer Chronik, 1484/85. Bern, Burgerbibliothek, Mss.h.h.I.16, f 764v. The larger the infantry force, the more stress it can take both psychologically and physically (Keegan, 1978:95), a cavalry charge presents both. A cavalry charge usually affects the first three ranks of an infantry body; in a formation eight ranks deep, this is not a large problem, as the cavalry will then start to flounder and the remaining ranks have the advantage. In a force of $20-80$, such a deep deployment is nearly impossible.

The composition of a lance means that out of a force of 15 , at least 5 are likely to have some kind of missile weapon, giving a wide range of possibilities to soften up the enemy before and during a charge. It was most likely common to use the missile weapons as a diversion to draw attention and cause confusion, then follow up with a charge by the concealed remaining cavalry forces. Or should the infantry form in a circle making a cavalry attack difficult the mounted crossbowmen or archers can fire into the formation.

The Earl of Derby made use of such tactics to great effect. At Bergerac in 1344 he used his archers to send advancing local levies fleeing into their supporting dismounted menat-arms defending a bridge over the waterway he followed with a charge with his own mounted men at arms with devastating results. Though Derby had 2,000 archers and 400 men-at-arms at his disposal, it is hard to judge the size of this engagement, as the bridge would not have allowed a full deployment on the French side. Later at 
Auberroche he used a similar tactic against a French force besieging the castle who were camped in a gentle valley. He placed his archers in a wood overlooking the French position and opened fire, taking the French by surprise. In the ensuing chaos he attacked along the mouth of the valley, his mounted forces charging the disorganised French. The victory was total and had a devastating effect on the French war effort (Burne, 1956:104.

For small engagements, the accounts we have from Ibn Usamah Munquidh seem even more relevant, as almost all of his experience was in such conflicts (Hitti 2000).

Tournaments as practice for ware may also give us an insight. Information that is to be gained from William Marshall's biography seem to indicate similar dynamics. Early tournaments also seem to have a focus on small unit engagements despite an initial split into two national teams (Duby, 1997:133) The tournament in those early days could often be as loosely defined as the land between two towns in order for the participants to set up ambushes and hide from one another (Barber and Barker, 2001:22). An incident in which the young king of England is almost captured, also seems to make a thickly packed mass of heaving horseflesh seem unlikely as it would pre-empt the described movements of the combatants (Duby, 1997:134-6). What is recorded as the most common method of taking control of your opponent, gaining control of the reigns and riding away with him in tow seems like-ways implausible unless cavalry combat was of an open and dynamic nature.

A simple truth of martial arts is that a static opponent is a dead one. This goes double for a horseman, a horse's ability to turn at a stand is as a quadruped, inferior to that of a human, this combines with the unavoidable lag in communications between horse and rider, so a cavalryman is even more vulnerable to an attacker from behind than an infantrymen. However a horse's ability to move improves once in motion. Constant motion is the cavalryman's friend making him both a harder target, adding force to his blows and letting him pick his targets. Dom Duarte in his treatise on riding gives this valuable advice when speaking of the tournament:

Returning to the tournament field, you should wound with no hesitation the first adversary you find on your way and go on looking for any other - but without turning your horse around - until you get back to the other end of the tournament field. Then, turning your horse back to return to the action, you bave time to see what's going on; if you see some of your friends surrounded by adversaries and fighting vigorously, you should gallop through the attack - destroying it with your action - and keep on galloping through the field, eventually finding another adversary to wound. Acting as described you get the following advantages:

1. Your performance is easily noticed by the audience.

2. Your strokes are stronger because you wound whom you decide and you will find many adversaries you can wound with no difficulty or danger for you. 
3. Your horse stays strong because you do not tire it with successive and abrupt changes of direction; rather you keep it at a steady gallop for most of the actions (Dom Duarte, ed. Preto \&Preto, 2006:115)

Speaking from experience, this is both highly practicable and effective advice. Although his advice is for the tournament melee, it holds just as true for a melee in action. It is worth bearing in mind that the first point, that your deeds are more easily spotted by the audience, was just as important in real combat as in the joust. Apart from the effects on the morale of other combatants, social status within a lord's retinue depended directly on personal prowess - where would William Marshal have been if his patrons had not seen his magnificent feats? A small number of riders each side enhances these dynamics. The lack of standing reserves makes the tactic less risky, and the chance for an organised retreat greater.

The picture on the right is a woodcut from the Thuròczy Chronicle (Ill. 5); it depicts the two phases of a small scale cavalry engagement. In the top half, we see clearly the initial contact, the lines are cleanly drawn and easily understood. In the top picture, the horses of the respective forces are all oriented in the same direction; by contrast, the bottom picture is a mess; gone are the thick packed ranks and lines, the horses turn into or away from the observer, all semblance of formation is lost.

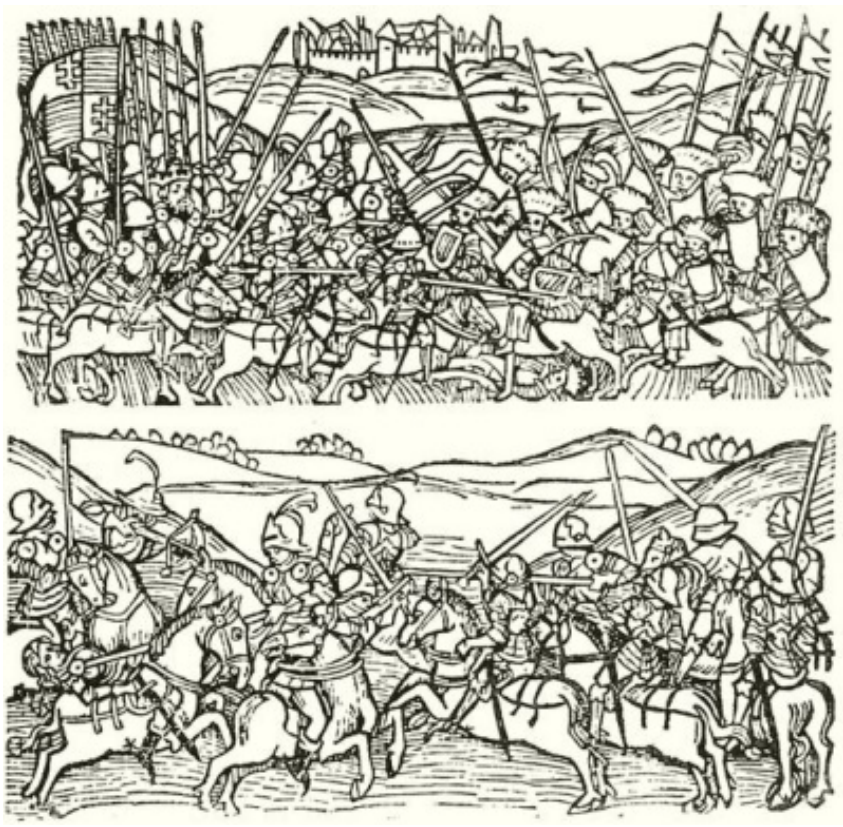

Ill. 5: Two groups of cavalry fighting, note the lines breaking in the lower balf.

János Thuróczy, Chronicaie Hungariae, Brünn by Conrad Stahel and Matthias Prenlein, 1488. 
Details that I find of particular note are: the crossbowman openly mixing in the engagement and firing at extreme close range; the horseman centre left, turning his horse in order to deny its head as a target and to escape his opponent. Also of note is the gait of the horses, they are all in a gallop or collected canter, depending on interpretation.

An intriguing question is how the mounted auxiliaries such as mounted crossbowmen worked in such a situation. Talhoffer includes mounted crossbow coming into contact with other combatants armed with swords and lances 10 ; Martin Huntfelz has pieces on: how to hold your crossbow in such a way that it shields your side "if your shot has missed" while you use your sword, in such a way that you may "return to spanning it"11; and on turn how best to keep your sword ready for action while using your crossbow. This is a very similar use to that of the crossbowman in the upper Thuróczy Chronicle illustration.

The illustration from Diebold Schilling shows a further situation typical for the depiction of mounted crossbowmen in artwork: when attacking a stronghold, cavalry as far back as the St. Gallen Golden Psalter and the Macjowski Bible are depicted with mounted crossbowmen or archers covering their advance, including an illustration supposedly from Froissart that I have not been able to trace which shows mounted longbowmen mixed among mounted men-at-arms, shooting to cover the charge during the battle of Blanchetaque.

\subsection{Conclusion}

It seems that field battles were rare occurrences, as both commanders usually preferred to employ a strategy of battle avoidance. Field battles were also not seen as the most worthy of engagements in which a knight could fight.

Considering the problems inherent for a mounted combatant, one realises that, contrary to popular belief, cavalry is extremely badly suited to breaking large bodies of formed and disciplined infantry; the only true advantage that cavalry possesses in this case is a psychological one. The historical record tells a similar story; cases in which large cavalry forces charged infantry forces frontally ended badly for the cavalry if the infantry did not break. As a result, a tactic of dismounting to assault became common, a tactic that brought some success.

The famous examples of frontal charges by cavalry against infantry - Crécy, Laupen and Courtrai - are also famous defeats. Successes of feudal cavalry against infantry Roosebeck, and (despite being commonly seen as an infantry victory) Murten - show a similar pattern. Each of these played on one of cavalry's strengths; at Roosebeck, the cavalry was held in reserve in order to attack the flanks at a crucial point, causing the infantry to flee (Tuchman, 1978:438). At Murten, a Burgundian force held a hedge that

10 MS Thott.290.2 $\mathrm{f}^{\circ} 94 \mathrm{v}-5 \mathrm{v}$ and Cod. Icon. 394a, $\mathrm{f}^{\circ} 135 \mathrm{r}-6 \mathrm{r}$.

11 Codex 44.A.8, f $^{\circ} 9 \mathrm{v}$. 
dominated the battlefield; had the Swiss infantry been forced to contend the hedge, the Burgundians would have had time to respond. Instead, an allied division of cavalry flanked the Burgundian force defending the obstacle, took them by surprise and cleared the hedge (Dürrenmatt, 1963:195-205).

They all share the common theme of using the cavalry's mobility to take the infantry by surprise, enhancing the psychological impact and denying the infantry any sort of advantage from their formation. Unfortunately, such successes tended to be the exception rather than the rule, and have lent feudal cavalry a bad name. The fact that medieval organisation was so poorly suited to field engagements seems to me yet more evidence that field engagements were not the main task of medieval armies - since if it had been, a better tool would have been fashioned for the purpose.

The units distilled from the lances lacked any kind of unit cohesion as their constituting elements would have been separated and recombined; considering the nature of medieval politics, discipline could become problematic (Delbrück, 2006:340).

The feudal order was complex and arguably fosters more independence than obedience. This was not a problem and was most likely beneficial as long as a nobleman was conducting his own private wars, or raiding on his own initiative. As soon as larger operations needed to be coordinated, the lack of a clear chain of command (Nicholson, 2004:50) could become disastrous. A weak commander could easily be steamrollered, with catastrophic results. This pattern is born out time and time again, at Courtrai, Poitiers, Agincourt, Nicopolis and other similar failures. Yet cavalry were still considered the premier fighting force, holding infantry in disdain and insisting on performing wild charges when given the chance. Why? It was obviously a product of overconfidence, but where did the overconfidence come from? A lack of experience with set-piece battles, maybe; but not likely from a total lack of experience with fighting. Looking at the dynamics of cavalry vs. infantry in small unit actions, we see a much different picture than in larger action engagements, it is much easier for cavalry to bring their force to bear, achieve the element of surprise and minimise casualties. In such a small engagement it seems likely that ranged auxiliaries were better integrated into the unit giving more effective cover fire to the cavalry.

Examining the dynamics of symmetrical cavalry engagements, we see a different pattern. The problems and advantages of manoeuvrability are cancelled out, making a frontal assault almost inevitable in a large engagement. The emphasis seems to lie with a strong formed charge to open the engagement - the aftermath is uncertain. Still, accounts point toward the lines being broken and a general degeneration into a dogfight-esque engagement with opponents pursuing each other. In large engagements, there are also examples of cavalry forces breaking through their counterparts and continuing on. The exact nature of large cavalry engagements is somewhat hard to tell. Some insight may be gleaned from the illustration from Wallhausen earlier in the book, but it is hard to say to what extent his treatise in its details holds for earlier periods. 


\section{CONCLUSION}

I set out to examine four aspects of feudal cavalry:

- What were the origins of feudal cavalry;

- What problems were they meant to address;

- What was the role of feudal cavalry; and

- What did cavalry engagements look like.

\subsection{Origins}

The origins of feudal cavalry forces lie in a Carolingian need for defensive mobility, and a strong elite force on which to hang an elaborate military machine. This force was well equipped and served in vanguard and expeditionary roles as well as forming the cavalry wing in field engagements. It was from in this feudally based mobile all-rounder that medieval cavalry had its beginning.

The Normans refined the offensive capabilities of small unit feudal cavalry, using their speed and superior training to swiftly take fortifications and subdue the surrounding land from there. Unfortified areas would then be fortified, and further Norman adventures be drawn in, using the lure of land and honours. This technique, which allowed small elite forces to command and control relatively large hostile areas, proved highly successful, from Wales to Palestine. This was the next step in the evolution of feudal cavalry.

\subsection{Challenges}

The success of the Norman Conquest meant that a similar pattern of fortification spread. Small but sturdy fortifications were built all over Europe. The mass fortification of the European landscape made the mass movement of large bodies of troops a huge military risk, as the same mobility and striking power that the Normans and Carolingians had against raiders could be used, with devastating consequences, against a marching column.

\subsection{The Nature of Feudal Cavalry}

Knights had opportunity, resource and motivation to become elite military units. They had no problem switching between roles traditionally assigned to later "heavy" or "light" cavalry.

The lance is by its nature a self-contained group of specialists well suited to independent action. It provided a one-stop shop for small unit actions, eliminating the need to assign troops from different units to provide a well-rounded force. The lance was a flexible and highly mobile operative unit.

The further fortification of the European landscape in combination with an imbalance in defensive vs. offensive capabilities led to a situation that made any attempt at massive troop movements almost impossible, due to the danger of getting bogged down, spread out or exposing the supply column to attack. The Norman operational doctrine of "take 
and hold" was expanded to include systematic targeting of enemy infrastructure. If a concerted attack in column was to be made against the enemy's heartland, it required that the enemy cavalry be forced into submission to the point that the column had free rein. It was this three-pronged nature of defensive harassment, take and hold and offensive raiding to subdue the enemy on a small unit basis that constituted the operational doctrine of medieval cavalry, and by such that their effectiveness should be judged.

\subsection{Dynamics of Cavalry Warfare}

Feudal cavalry were due to their organisation and essential nature badly suited to fighting infantry in large field engagements where terrain could be used to the infantry's advantage to protect their flanks and hamper the charge. Should the infantry not break on first contact, the cavalry are in an extremely bad position. Cavalry engagements seem to have relied heavily on initial striking power to achieve a breakthrough and either continuation to a further target or open combat. Also vital was the correct use of reserves.

Small unit engagements most likely favoured cavalry over infantry as cavalry could have likely used their mobility to pick favourable positions, and high depth of rank would have been hard to achieve. Small unit action pitting cavalry against cavalry followed a similar pattern to large action engagements, with a higher emphasis on mobility and integration of the lances' auxiliary units, especially mounted crossbow.

\subsection{General Conclusion}

The operational doctrine of feudal cavalry was one that played out at a very small unit level, and it was here that it fulfilled its most vital military role. Historians because of their seeming decisiveness and a focus on field battles in contemporary warfare have judged the effectiveness of feudal cavalry and by extent the knight on feudal cavalry's effectiveness in field battles. This is the wrong approach. Any attempt to examine or judge the methods or performance of medieval cavalry must keep small unit action in the forefront of the mind, and field battles second.

It was in this type of warfare that the Lichtenauer and 14th Italian schools had their origin. It was this context that defined the day-to-day routine and importance of medieval warfare. The fact that the knight and by extent cavalry were deemed in their own time the premier fighting force of the age is a result of effectiveness on the small unit level.

Field engagements were not the knights' primary operational doctrine; they were a job for which, as a cavalry force, they were least suited to, especially with the integration of disciplined infantry. Their overconfidence in a single frontal charge against infantry in such engagements, and their overall dismissal of infantry forces in general, was most likely born from experience with a form of warfare where cavalry possessed the upper hand against infantry. Although they may seem to be the same thing, the dynamics of a 
feudal cavalry charge fail to scale: a charge by 10 or 30 against $20-80$ is a vastly different beast from 200 against 400-600, especially since in large engagements, the men-at-arms cannot be properly supported by their auxiliary troops.

\section{OUTLOOK}

The death of feudal cavalry goes hand in hand with the death of feudalism as well as the rise of powerful centralist monarchs and strong cities. The increasing shift towards more rigid centralist political organisation seems to follow a rise of more professional infantry, gains in siege capabilities over fortifications and concentration of economic power in well organised cities, thus making the pattern of raiding rural production centres and withdrawing into impenetrable defences no longer sensible, as the lasting economic effect would be minimal. Cities and trade provided the commander with the logistics and means to organise troops on a financial rather than feudal basis.

This movement, already begun in the $13^{\text {th }}$ century with the shift from an agricultural economy to a monetary one, culminated in the Renaissance. Trained city militias assumed the main battle role; cavalry were forced to don heavier and heavier armour and provide larger, more expendable cavalry divisions both for battlefield and operational roles, forcing a split. Cavalry became less and less crucial. The $2^{\text {nd }}$ estate took to the newly created officer roles within the new infantry-focused armies of the late $16^{\text {th }}$ century. With the new focus on field battles, warfare, society and cavalry changed dramatically (Arnold, 2001:54). 


\section{REFERENCE LIST \\ Primary sources}

Anonymous, Bayeux Tapestry, ca. 1066. Bayeux, Musée de la Tapisserie de Bayeux.

Anonymous, Golden Psalter, ca. 850-900. St. Gallen, Stiftsbibliothek, Cod. Sang. 22.

Anonymous, L’histoire de Guillaume le Maréchal, 1219-1226. Transl. Kaiser, Reinhard (1997):

Guillaume le Maréchal oder der Beste aller Ritter. [based on Duby, 1986]. Frankfurt a.M.: Suhrkamp.

Anonymous, Manesse Codex, 1310-1340. Heidelberg Universitätsbibliothek, Cod. Pal. germ. 848.

Anonymous, Morgan Bible, ca. 1250. New York, The Pierpont Morgan Library, Ms M. 638.

Anonymous, Speculum regale, ca. 1250. Ed. Larson, Laurence Marcellus (1848). London: Oxford University Press.

[online:http://www.hroarr.com/manuals/other/Speculum_regale_Konungs_skuggsj__K ong.pdf, accessed 28.02.2014]

Anonymous, Venus und Mars. Das mittelalterliche Hausbuch aus der Sammlung der Fürsten von Waldburg Wolfegg, 1480. Ed. [facsimile] Waldburg Wolfegg, Christoph (1997). New York: Prestel.

Diebold Schilling, Spiezer Chronik, 1484/85. Bern, Burgerbibliothek, Mss.h.h.I.16. [online: http://www.e-codices.unifr.ch/en/bbb/Mss-hh-I0016, accessed 28.02.2014]

Dom Duarte, Livro Da Ensinança De Bem Cavalgar Toda Sela, 1438. Transl. Preto, Antonio Franco \& Preto, Luis (2006): The Royal Book of Horsemanship. Chivalry Bookshelf.

Edward of Norwich, The Master of Game, 1406-1413. Ed. William. A. and Baillie-Grohman, F. N. (2005). University of Pennsylvania Press.

Fiore dei Liberi, Fior di Battaglia, ca. 1400. New York, Morgan Library, MS M.383.

Flavius Mauricius Tiberius Augustus, Strategikon, 602. Ed. Dennis, T. Georges (1984): Maurice's Strategikon: Handbook of Byzantine Military Strategy. University of Pennsylvania Press, 1984.

Geoffrey Chaucer, The Canterbury Tales, late 14th c. Transl. Coghill, Nevill (1994). London: Penguin.

Hans Talhoffer, Fechtbuch, 1459. Kopenhagen, Det Koneglige Bibliothek, Thott $2902^{\circ}$.

Jan Dlugosz, Annales seu Cronicae incliti regni Poloniae, 1480. Transl. Maurice, Michael (1997): The Annals of Jan Dlugosz: A History of Eastern Europe from A.D. 965 to A.D. 1480. Chichester: IM Publications.

János Thuróczy, Chronicaie Hungariae, Brünn by Conrad Stahel and Matthias Prenlein, 1488.

Joanot Martorell, Tirant Lo Blanc, 1489. Transl. Rosenthal David (1984). New York: Schocken Books.

Johan Jacobi von Wallhausen, Ritterkunst, Frankfurt am Mayn bei Iennis, 1614. [online, http://www.hroarr.com/manuals/other/Wallhausen-Johann-Jacobi-von-RitterkunstDarinnen-begriffen-1614.pdf, accessed 28.02.2014]

Martin Huntfelz in Peter von Danzig's Fechtbuch, 1452. Ed. Hagedorn, Dierk (2008): Peter von Danzig: Transkription und Übersetzung der Handschrift 44 A 8. Vs-Book.

Niccolò Machievelli, Il Principe, 1513 [published 1532]. Transl. Marriott, W. K. and Baker-Smith, D. (1992): The Prince. [1st ed. 1952].

Pausanius, Pausaniae Veteris Graeciae descriptio, 115-180. Transl. Peter Levi (1984): Guide to Greece 1: Central Greece. London:Penguin books. 
Sébastien Mamerot, Passages faiz oultre mer, 1472-75. Paris, Bibliothèque nationale de France, ms. 5594

Usamah Ibn-Munqidh, Kitab al-I'tibar, 1140-1200. Transl. Hitti, Philip K. (2000): An Arab-Syrian Gentleman and Warrior in the Time of the Crusades. [1st ed. 1929]. New York: Columbia University Press.

\section{Secundary literature}

Akdahl, Sven (1998): "Horses and Crossbows: Two important warfare advantages of the Teutonic order in Prussia”. In: Nicholsen Helen (ed.) (1998): The military orders, volume 2: Welfare and Warfare. Aldershot: Ashgate.

Arnold, Thomas \& Keegan, John (2001): The Renaissance at War. London: Cassel.

Bachrach, Bernard S. (2001): Early Carolingian Warfare: Prelude to an Empire. Philadelphia: University of Pennsylvania Press.

Barber, Richard \& Barker, Juliet (2001): Die Geschichte des Turniers. Transl. from English by Herald Ehrhardt, Darmstadt: Wiss. Buchges.

Beck, Wilhelm (1911): "Bayerns Heerwesen und Mobilmachung im 15. Jahrhundert“, in Archivalische Zeitschrift (31), p.1-232.

Bennet, Matthew (1989):"La régle du Temple as a Military Manual or How to Deliver a Cavalry Charge". In: Harper-Bill, C.; Holdsworth, C.-J. and Nelson, J. L. (eds.): Studies in medieval history presented to R. Allen Brown. Wolfeboro: Boydell Press.

Bumke, Joachim (2008), Höfische Kultur Literatur und Gesellschaft im Hohen Mittelalter [1st ed. 1986]. München: Deutscher Taschenbuch Verlag

Burne, Alfred Higgins (2002); The Hundred Years War. Reprint, 1st ed. 1955 and 1956. London: Penguin (Classic military history).

Chandler, Jean Henri (2013): “A Brief Examination of Warfare by Medieval Urban Militias in central and Northern Europe”, Acta Periodica Duellatorum (1), p. 106-150.

Clark, John (ed.) (2011): The Medieval Horse and its equipment. Woodbridge: Boydell Press.

Contamine, Philippe (1986): War in the Middle Ages. Transl. Michael Jones [1st ed. 1980]. Oxford: Blackwell Publishing ltd.

Davis, R.H.C. (1989): The medieval Warhorse. London: Thames and Hudson Ltd.

Delbrück, Hans (2000): Geschichte Der Kriegskunst: Das Mittelalter von Karl dem Grossen bis zum späten Mittelalter. [reprint, 1st ed. 1907]. Hamburg:Nikol Verlag.

Dürrenmatt, Peter (1957): Schweizer Geschichte. Bern: Verlag Hallwag.

Gillingham, John (1999):"An Age of Expansion“. In: Keen, Maurice (ed.): Medieval Warfare: A History. New York: Oxford University Press, p. 59-88.

Harari, Yuval Noah (2004): Renaissance Military Memoirs, War, history and Identity, 1450-1600. New York: Boydell Press.

Harari, Yuval Noah (2007): Special Operations in the Age of Chivalry, 1100-1550. Woodbridge: Boydell Press.

Hyland Ann(1996): The medieval warhorse from Byzantium to the Crusades. s.l.: Sutton Publishing Ltd 
Jones, Robert (2008): "Rethinking the Origins of the Irish Hobelar". In: Cardiff Historical Papers (1). [online, http://www.academia.edu/443379/Re-thinking_the_Origins_of_the_Irish_Hobelar, accessed 28.02.2014]

Keegan, John (1978): the Face of Battle. [1st ed. 1976]. London: Penguin Books

Keegan, John (1993): A History of Warfare. New York: Alfred A. Knopf.

McGlynn, Sean (2008): By Sword Fire, Cruelty and Atrocity in Medieval Warfare. London: Pheonix.

Morris, Marc (2008): A great and terrible King: Edward I and the forging of Britain. London: Hutchinson.

Nicholson, Helen (2004): Medieval Warfare Theory and Practice of War in Europe 300-1500. New York: Pallgrave Macmillan.

Reuther, Timothy (1999): "Carolingian and Ottomonian warfare". In: Keen, Maurice (ed.):

Medieval Warfare: A History. New York: Oxford University Press, p. 12-34.

Smail, Raymond Charles (1995): Crusading Warfare, 1097-1193. [1st ed. 1956] Cambridge: University Press.

Stephenson, Carl (1956): Medieval Feudalism. [1st ed. 1942]. Cornell University Press.

Verbruggen, Jan-Frans (1997): The Art of Warfare in Western Europe During the Middle Ages. Transl. Williard Sumner [1st ed. 1956]. Woodbridge:Boydell Press, 1997

Zeumer, Karl (1913): Quellensammlung zur Geschichte der Deutschen Reichsverfassung in Mittelalter und Neuzeit. Tübingen, Verlag von J.C.B. Mohr. 